\title{
Erythrocyte Transport Function in Cystic Fibrosis
}

\author{
Stephen A. Feig, ${ }^{[17]}$ George B. Segel, Kenneth A. Kern, Alan B. Osher, \\ and Robert H. Sahwartz \\ Gwynne Hazen Cherry Memorial Laboratory, the Department of Pediatrics, UCLA School of Medicine, Los Angeles, California, \\ and Department of Pediatrics, University of Rochester School of Medicine and Dentistry, Rochester, New York, USA
}

\section{Extract}

ATPase activity and monovalent cation transport were examined in erythrocytes (RBC) of subjects with cystic fibrosis (CF). The RBC membrane $\left(\mathrm{Ca}^{2+}\right)$ ATPase activity of homozygous patients and obligate heterozygotes was indistinguishable from that of normal control subjects. This was true similarly for total, ouabain-sensitive, and ouabain-insensitive $\left(\mathrm{Na}^{+}-\mathrm{K}^{+}\right)$ATPase.

Total, ouabain-sensitive, and ouabain-insensitive ${ }^{24} \mathrm{Na}^{+}$transport were normal in CF cells. Ouabain-induced $\mathrm{Na}^{+}$accumulation was similar in $\mathrm{CF}$ and normal RBC. Measurements of $\mathrm{K}^{+}$transport in CF RBC were, likewise, normal.

We conclude that intrinsic ATPase and monovalent cation transport functions are normal in CF RBC. We were unable to confirm several abnormalities in these cells reported previously. The CF RBC is not helpful in defining a transport abnormality in that entity.

\section{Speculation}

These studies document normal intrinsic transport function in $\mathrm{RBC}$ of patients with GF. There have been recent reports of an abnormal serum factor in patients with $\mathrm{CF}$. This factor might be involved in the production of a transport defect in GF. Further studies are indicated to determine whether CF plasma contains a factor capable of altering membrane transport functions of normal RBC.

\section{Introduction}

An increase in the $\mathrm{Ca}^{2}+$ or $\mathrm{Na}^{+}$content of various body secretions has reported consistently in patients with CF. This has suggested the presence of a membrane transport defect to many investigators. Because of their ease of availability, RBC have been studied by several workers in an attempt to document an abnormal transport mechanism. The results of these investigations have been remarkably inconsistent.

The content of $\mathrm{Na}^{+}$in CF RBC has been uniformly normal [2, 3, 9]. Balfe et al. [2] have described a small decrease in ouabain-sensitive $\mathrm{Na}^{+}$efflux, and a marked reduction in the ouabain-insensitive $\mathrm{Na}^{+}$efflux. This latter was caused by deficiencies in both the ethacrynic acid-sensitive and -insensitive portions. Paradoxically, they noted decreased ouabain-sensitive ( $\mathrm{Na}^{+}$$\left.\mathrm{K}^{+}\right)$ATPase in CF erythrocyte membranes, whereas the ouabain-insensitive portion was normal.

Lapey and Gardner [9] have also observed a decrease in the ethacrynic acid-sensitive portion of $\mathrm{Na}^{+}$ efflux in RBC of homozygous $\mathrm{CF}$ males and older females, but the RBC transport function of younger female subjects and heterozygotes was normal. They did not report any studies of RBC ATPase activity.

Cole and Dirks [3] have examined ATPase activity in CF RBC, but have not studied $\mathrm{Na}^{+}$transport. They observed normal ouabain-sensitive ATPase and dimin- 
ished ouabain-insensitive ATPase in CF RBC membranes. Cole and Dirks also studied the effect of preincubation of normal RBC in CF and normal plasma. Their data suggests that CF plasma may contain a factor which reduces the ouabain-sensitive but not the ouabain-insensitive ATPase of normal cells [3].

Horton et al. [8] have studied ATPase activity in $\mathrm{RBC}$ of CF heterozygotes and homozygotes. They reported normal $\left(\mathrm{Na}+-\mathrm{K}^{+}\right)$- and $\left(\mathrm{Mg}^{2+}\right)$ ATPase activities, but decreased $\left(\mathrm{Ca}^{2+}\right)$ ATPase activity in CF homozygotes. The degree of abnormality was directly proportional to the clinical severity of disease. They found normal ATPase activities in the RBC of heterozygotes, however.

Hadden et al. [6] have recently reported totally normal ${ }^{86} \mathrm{Rb}$ and ${ }^{85} \mathrm{Sr}$ transport in CF erythrocytes. Because $\mathrm{Rb}^{+}$and $\mathrm{Sr}^{2+}$ are transported by the same mechanisms as $\mathrm{Na}+$ and $\mathrm{Ca}^{2+}$, respectively, they inferred that $\mathrm{Na}+$ and $\mathrm{Ca}^{2+}$ transport is normal in $\mathrm{CF}$ cells. These authors observed no deficiency of ethacrynic acid-sensitive $\mathrm{Na}+$ efflux.

We have studied CF RBC membranes in an attempt to clarify the rather confusing picture created by this contradictory series of previous reports. We were totally unable to confirm any abnormality of ATPase function in CF heterozygotes or homozygotes, and also failed to confirm any abnormality of $\mathrm{Na}^{+}$or $\mathrm{K}+$ transport in CF RBC.

\section{Methods}

Patients with CF were selected from the clinics of the UCLA Center for the Health Sciences and the Strong Memorial Hospital on the basis of their willingness to undergo venipuncture. Obligate heterozygotes were similarly chosen from among the mothers of CF patients. Normal subjects were chosen at random from the clinical, laboratory, and secretarial staffs of the clinics.

For the ATPase assays, cells were washed and lysed by the method of Nakao et al. [11]. Protein content was determined by the method of Lowry et al. [10]. Incubations for $\left(\mathrm{Na}^{+}-\mathrm{K}^{+}\right) \mathrm{ATP}$ ase were performed by the method of Post et al. [13]. Filtrates were prepared with cold $10 \%$ trichloroacetic acid.

Incubations for $\left(\mathrm{Ca}^{2+}\right)$ - and $\left(\mathrm{Mg}^{2+}\right) \mathrm{ATP}$ ase were

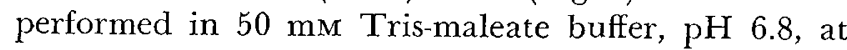
which $\mathrm{pH}$ maximum activity was obtained [4]. The $\left.\mathrm{Mg}^{2+}\right) \mathrm{ATP}$ ase was defined as the inorganic phosphate $\left(\mathrm{P}_{\mathrm{i}}\right)$ liberated from ATP in the presence of $\mathrm{Mg}^{2+}$ less that liberated in the absence of $\mathrm{Mg}^{2+}$. $\left(\mathrm{Ca}^{2+}\right)$ ATPase was defined as the $\mathrm{P}_{\mathrm{i}}$ liberated in the presence of $\mathrm{Mg}^{2+}$ and $\mathrm{Ca}^{2+}$, less that liberated in the presence of $\mathrm{Mg}^{2+}$ alone. The concentrations of $\mathrm{Mg}^{2+}(0.01 \mathrm{M})$ and $\mathrm{Ca}^{2+}$ $(0.001 \mathrm{M})$ were chosen to maximize the reaction rate [4]. The concentration of free $\mathrm{Ca}^{2}+$ was calculated from the binding constant of ethylene glycol tetraacetic acid [12] which was present in a final concentration of $0.001 \mathrm{M}$. ATP was present in a concentration of $0.0025 \mathrm{M}$, which provided maximum reaction velocity.

The reaction was performed in a volume of $0.5 \mathrm{ml}$ at $37^{\circ}$ in an oscillating water bath. The reaction was started by the addition of Tris-ATP, neutralized with $\mathrm{KOH}$. It was stopped by the addition of $0.5 \mathrm{ml}$ iced $10 \%$ trichloroacetic acid.

All ATPase incubation filtrates were analyzed for the concentration of $P_{i}$ by the method of Ames and Dubin [1]. To avoid thermal hydrolysis of ATP, the color was allowed to develop at room temperature and a standard curve of $O D$ versus $\left[\mathrm{P}_{i}\right]$ was performed with every experiment.

Measurements of ${ }^{24} \mathrm{Na}+$ and ${ }^{42} \mathrm{~K}+$ transport were performed [5]. Ouabain-induced $\mathrm{Na}+$ accumulation and $\mathrm{K}+$ loss were also measured without isotopes. All transport incubations were performed in Krebs-Henseleit buffer as described previously [5].

\section{Results and Discussion}

Initial studies of the $\mathrm{Ca}^{2+}$ and $\mathrm{Mg}^{2+}$-ATPase activities of CF erythrocyte membranes were entirely within

Table I. ATPase activity of cystic fibrosis (CF) erythrocyte membranes ${ }^{1}$

\begin{tabular}{|c|c|c|c|c|c|}
\hline & \multirow{2}{*}{$\left(\mathrm{Mg}^{2+}\right) \mathrm{ATP}$ ase } & \multirow{2}{*}{$\left(\mathrm{Ca}^{2+}\right)$ ATPase } & \multicolumn{3}{|c|}{$\left(\mathrm{Na}^{+}-\mathrm{K}^{+}\right)$ATPase } \\
\hline & & & Total & Ouabain sensitive & Ouabain insensitive \\
\hline Normal & $205 \pm 82$ & $594 \pm 276(64)$ & $488 \pm 151$ & $275 \pm 113$ & $202 \pm 76$ \\
\hline CF homozygotes & $244 \pm 71(24)$ & $671 \pm 245(24)$ & $467 \pm 114(20)$ & $239 \pm 64$ & $228 \pm 123(20)$ \\
\hline CF heterozygotes & $237 \pm 68(15)$ & $692 \pm 300(15)$ & $494 \pm 85$ & $293 \pm 58$ & $200 \pm 61$ \\
\hline
\end{tabular}

1 Activity expressed as nanomoles of $\mathrm{P}_{\mathrm{i}}$ liberated per milligram of protein per hour \pm SD. Numbers in parentheses indicate number of observations. 
Table II. Monovalent cation transport in cystic fibrosis (CF) erythrocytes ${ }^{1}$

\begin{tabular}{|c|c|c|c|c|}
\hline & \multicolumn{2}{|c|}{$\mathrm{K}^{+}$} & \multicolumn{2}{|c|}{$\mathrm{Na}^{+}$} \\
\hline & $\mathrm{CF}$ & Normal & $\mathrm{CF}$ & Normal \\
\hline \multicolumn{5}{|l|}{ Isotope flux } \\
\hline Total & $1.6 \pm 0.1)$ & $1.7 \pm 0.3)$ & $3.1 \pm 0.3)$ & $2.9 \pm 0.3$ \\
\hline Ouabain sensitive & $1.2 \pm 0.1\}(4)$ & $1.3 \pm 0.3\}(6)$ & $2.2 \pm 0.2\}(4)$ & $2.0 \pm 0.2\}(6)$ \\
\hline Ouabain insensitive & $0.4 \pm 0.1$ & $0.4 \pm 0.1$ & $0.8 \pm 0.1$ & $0.9 \pm 0.2$ \\
\hline \multicolumn{5}{|l|}{ Nonisotope flux } \\
\hline $\begin{array}{l}\text { Ouabain induced }\left(\mathrm{K}^{+} \text {leak or } \mathrm{Na}^{+}\right. \\
\text {accumulation) }\end{array}$ & $1.2 \pm 0.3$ & $1.2 \pm 0.1$ & $1.5 \pm 0.2$ & $1.4 \pm 0.1$ \\
\hline
\end{tabular}

${ }^{1}$ Values expressed as milliequivalents per liter of cells per hour $\pm \mathrm{SD}$. Numbers in parentheses indicate number of observations.

normal limits (Table I). We could not confirm the deficiency of $\mathrm{Ca}^{2+}$-ATPase reported by Horton et al. [8]. No abnormalities were observed in CF heterozygotes.

Furthermore, examination of $\left(\mathrm{Na}^{+}-\mathrm{K}^{+}\right)$ATPase activity did not suggest any abnormality in homo- or heterozygote CF erythrocyte membranes (Table I). Our data do not support the previous observations of decreased ouabain-sensitive [2] or ouabain-insensitive [3] $\left(\mathrm{Na}+. \mathrm{K}^{+}\right)$ATPase.

Active $\mathrm{Na}^{+}$and $\mathrm{K}+$ transport were examined in normal and homozygote CF erythrocytes (Table II). Potassium flux, measured by isotope influx or ouabaininduced loss, was entirely normal in CF RBC. Studies of $\mathrm{Na}+$ flux in $\mathrm{CF}$ cells were entirely within normal limits also.

We calculate from the data of Balfe et al. [2] a $44 \%$ decrease in ouabain-insensitive $\mathrm{Na}^{+}$efflux. The calculation is based upon the observation of Hoffman [7] that the ethacrynic acid-sensitive portion is at least $65 \%$ of the ouabain-insensitive efflux. Our data show no significant decrease in ouabain insensitive $\mathrm{Na}+$ efflux in CF erythrocytes. Therefore, no further studies to dissect the ouabain-insensitive efflux seemed to be indicated.

\section{Summary}

These studies demonstrate normal transport function in CF RBC. They were performed on membranes and intact cells in a buffer system. Although the intrinsic transport capability of these cells is normal, these experiments do not examine any effect of CF plasma on normal RBC function. In view of the observations of a factor in CF serum capable of affecting cellular functions [14], further studies must be performed to deter- mine whether this factor is capable of altering RBC function, as suggested by Cole and Dirks [3].

\section{References and Notes}

1. Ames, B. N., And Dubin, D. T.: The role of polyamines in the neutralization of bacteriophage desoxyribonucleic acid. J. Biol. Chem., 235: 769 (1960).

2. Balfe, J. W., Cole, C., AND WeLt, L. G.: Red-cell transport defect in patients with cystic fibrosis and their parents. Science, 162: 689 (1968).

3. Cole, C. H., AND Dirks, J. H.: Changes in erythrocyte membrane ATPase in patients with cystic fibrosis of the pancreas. Pediat. Res., 6: 616 (1972).

4. FEIG, S. A.: Relative deficiency of $\mathrm{Ca}^{2+}$-ATPase activity of red cell membranes in hereditary spherocytosis (Submitted for publication).

5. Feig, S. A., Segel, G. B., Shohet, S. B., and Nathan, D. G.: Energy metabolism in human erythrocytes. II. Effects of glucose depletion. J. Clin. Invest., 51: 1547 (1972).

6. Hadden, J. W., Hansen, L. G., Shapiro, B. L., and Warwick, W. J.: Erythrocyte enigmas in cystic fibrosis. Proc. Soc. Exp. Biol. Med., 142: 577 (1973).

7. Hoffman, J. F.: The red cell membrane and the transport of sodium and potassium. Amer. J. Med., 41: 666 (1966).

8. Horton, C. R., Cole, W. Q., And Bader, H.: Depressed $\left(\mathrm{Ca}^{++}\right)$transport ATPase in cystic fibrosis erythrocytes. Biochem. Biophys. Res. Commun., 40: 505 (1970).

9. LAPEY, A., AND GaRDNER, J. D.: Abnormal erythrocyte sodium transport in cystic fibrosis (CF). Pediat. Res., 4: 478 (1970).

10. Lowry, O. H., Rosebrough, N. J., FarR, A. L., ANd Randall, R. J.: Protein measurement with the Folin phenol reagent. J. Biol. Chem., 193: 265 (1951).

11. NakaO, K., Kurashina, S., and Nakao, M.: Adenosine triphosphatase activity of erythrocyte membrane in hereditary spherocytosis. Life Sci., 6: 595 (1967).

12. Ogawa, Y.: The apparent binding constant of glycoletherdiamine-tetraacetic acid for calcium at neutral $\mathrm{pH}$. J. Biochem. Tokyo, 64: 255 (1968).

13. Post, R. L., Merritt, C. R., Kinsolving, C. R., and Albright, C. D.: Membrane adenosine triphosphatase as a participant in the active transport of sodium and potassium in the human erythrocyte. J. Biol. Chem., 235: 1796 (1960).

14. Spock, A., Heick, H. M. C., Cress, H., and Logan, W. S. 
Abnormal serum factor in patients with cystic fibrosis of the pancreas. Pediat. Res., 1: 173 (1967).

15. The authors appreciate the excellent technical assistance of Mr. Paul Dutcher and Mrs. Sara Bassilian.

16. This research was-supported in part by General Research Support Grant no. RR 5354 from the United States Public
Health Service and by grants from the National Cystic Fibrosis Research Foundation.

17. Requests for reprints should be addressed to: S. A. FeIG, M.D., Department of Pediatrics, UCLA School of Medicine, Los Angeles, California 90024 (USA).

18. Accepted for publication January 14, 1974. 